\title{
A global conversation: rethinking IPE in post-hegemonic scenarios*
}

Diana Tussie** and Pia Riggirozzi***

\section{Introduction}

Jerry Cohen's influence over the development of international studies is beyond doubt. The very fact that we are painfully aware, and rightly so, of the political role of currencies is due in large part to the endurance of his work. Since his seminal work Organizing the world's money (1977), Cohen has constantly reminded us that the political order/rule embedded in the monetary order is made up of systematic biases which favour some policies, and undermine the capacities and preferences of subaltern actors. In other words, the international political economy is essentially about chains of domination and dependence. The burden of austerity first rested on

\footnotetext{
* Received on March $19^{\text {th }} 2015$ and approved for publication on May $13^{\text {th }} 2015$.

** Head of the Department of International Relations at the Argentine Campus of the Facultad Latinoamericana de Ciencias Sociales, Autonomous City of Buenos Aires, Argentina. Email: dtussie@flacso.org.ar.

*** Associate Professor in Global Politics at the University of Southampton, Southampton, Hampshire, United Kingdom. Email: P.Riggirozzi@soton.ac.uk.
} 
Latin America, but has now shifted to southern Europe. It is in this context that Cohen's work continues to resonate and gain influence.

There is much to be learnt from the experiences of Latin America, a region buffeted by economic crises during the 1980s and 1990s, amid attempts to build more imaginative and more inclusive forms of governance. Latin America began to increase economic growth and stabilise governance by embracing moderate reforms and increasing spending on welfare, health, education and infrastructure, in a context of fiscal restraints and rising exports. This middle way between an open market and a statist political economy has been termed 'post-neoliberal politics' and/or 'neo-structural economics', and has gone hand in hand with programmes to enhance social inclusion (Grugel and Riggirozzi 2012). It is not without its problems, but has nevertheless attracted significant voter support, and has played a key role in the return to democracy in the region. At the same time, the normative and geopolitical conditions that allowed the United States and institutions sponsored by it to dominate inter-American relations for decades have shifted. Since the early 2000s, ideological polarisation and divergent approaches to hemispheric governance have meant that new regional institutions are reclaiming the region and rebuilding inter-American relations, forcing Washington and Washington-based institutions to accommodate other interests if they are to retain a degree of influence in the process. The challenge is not merely one of symbolic politics led by left-leaning presidents railing against American domination. Relations between the United States and Latin America face a profound change in the co-ordinates of regional power, diplomacy, and co-operation. The 'post-hegemonic' region-building manifested in a reorganisation of the regional scenario and the emergence of new institutions such as the Bolivarian Alliance of the Americas (ALBA) in 2004, the Union of South American Nations (UNASUR) in 2008, and the Community of Latin American and 
A global conversation: rethinking IPE in

post-hegemonic scenarios

Caribbean States (CELAC) should be seen as manifestations of this trend (Riggirozzi and Tussie 2012).

What this context reveals is a change in the political role of market rules, drawing attention to a classic issue in the Latin American approach to IPE, namely the conditions leading away from dependence to autonomous development (Cohen 2014) now possible in a new scenario, and driven by new policies of post-hegemonic regionalism (Riggirozzi and Tussie 2012). We argue that regions and regionalism matter because IPE unfolded with a continued focus on global structures, while the structural phenomena in other policy and geographical spaces were brushed aside. For Cohen, this was more the case because Latin American scholars could not sustain the academic and policy relevance they had achieved from the 1960s onwards (2014: 94). However, Latin American scholars could have lost their visibility not only because of economic turmoil and political authoritarianism, but also because of IPE was dominated by what Cohen (2007) denounced as the transatlantic divide, or Atlanticism.

IPE scholars now have a genuine opportunity to transcend that divide and to interrogate how regions in the South, and Southern regionalisms, become political spaces where policies are redefined and norms of global political economy reworked. Changes in the political economy of Latin America must be seen as an invitation to engage afresh with the role of regions, and regional actors, as they become part of what defines the rules of and in IPE. Cohen has aptly remarked that geography is politics, and that how we conceive of space has a real impact on how we think about rule-making (1998: 10). A focus on regions and regionalism, as a privileged space where politics happen, has often been out of sight and understudied in IPE. Therefore, a global conversation is needed if we want to live in a discipline that is about a wider world than the one that occupied the transatlantic divide. This article suggests that geography matters for 
IPE because of what a geographical focus adds to its intellectual diversity. Regions offer a political space from which to reinterpret core political and economic issues that shape the global political economy as practice and as an agenda of enquiry. The analysis is addressed as follows.

First, we scrutinise the question of IPE's global span, building upon well-trodden arguments about its wilting claim to be global. Next, we analyse the intellectual trajectory of regions and regionalism as an often trivialised concept in IPE. We claim that this is not necessarily due to academic neglect, but rather a consequence of how regions in the South were captured by the ideological, political and geographic constrictions of the Cold War. Lastly, we move towards a new research agenda that engages with current changes in the global political economy and the regional political economy in the Americas, and asks whether the focus on social development, welfare and inclusion has implications for the way in which we theorise about regionalism in IPE. In doing so, we move from the classical conception of regions as spheres of influence to region as pivotal spaces where politics are (re)thought, and happen 'from the nation up'. Regions as geography and regionalism as governance call for a sui generis place in in an extended global conversation about the nature and contours of IPE in theory and practice.

\section{How global is IPE?}

Whether the origins of IPE are attributed to the splintering away from conservatism in international relations (IR) in order to focus more on economic phenomena, or to a heightened interest in a resurgent classical economic sociology, its emergence and ongoing institutionalisation within academia is a cause for celebration. IPE is, of course, a divided discipline. Many 'mainstream' IPE theorists retain the rationalist and behaviourist assumptions of positivist branches of 'traditional' IR. 'Mainstream' is used here to mean 
A global conversation: rethinking IPE in

post-hegemonic scenarios

simply 'non-critical'; it is not meant to denote that critical IPE, rooted in radical social science, is not as popular or as important within the discipline. In academic institutions in some parts of the world, critical IPE, not positivism, can be seen to hold the status of quasi-orthodoxy. In Latin America for one, there is a rich literature in this regard that engages with multiple schools of Marxism rather than mainstream or transatlantic IPE. ${ }^{1}$ Attitudes toward Marxism or other leftist doctrines and dissimilar concerns about inequality and development explain this 'dialogue of the deaf', as Craig Murphy (2011) has pointed out. These contributions, which can be split in various ways, have seldom found favour with the mainstream discipline.

The fact remains, though, that mainstream IPE makes a major contribution to scholarly enquiry by opening up the traditional concerns of IR: the interaction of states; the emergence and operation of multilateral institutions; order and stability in the international system, and the position of the United States as a hegemonic power. This differs from traditional IR in that it introduces a concern with economic factors and market rules in a non-Marxist epistemology, and the belief that these are as important, if not more so, than political and military relations. 'What other government could have spent more than 500 billion dollars on a war in Iraq? No one else could have done that. The United States can do that only because of the international position of the dollar as the world's main currency' (Cohen 2008a, quoted in Schouten). When Cohen launched the debate on the 'transatlantic divide', he reckoned that IPE had become 'normalised', and needed to confront a changing international system. A normalised IPE was bound to miss out on these changes, and would not have addressed the normative and distributive consequences of these transformations.

Part of the problem lies in the discipline's Anglo-American bias, the product not only of an overrepresentation of North American and 
British scholars and publications, but also of a community's construction of an object of study that is defined by the same community. Mainstream IR and IPE were born as extensions of imperial concerns. Thus a restricted focus, even a self-styled demarcation, was born: 'l'etat c'est moi'. This organisational boundary-setting framed foundational questions, while other intellectual parameters and empirical referents did not reach the radar screen (of the debate, conference circuits, journals, funding, and so on). Furthermore, alternative traditions were often neglected and at times even deprecated as too ideological or as smacking of journalism.

Mainstream IPE ignored indigenous bodies of literature, or relegated them to the status of 'area studies' - a conception that still shapes IPE in Latin America as an activity on the periphery of the mainstream project. This conception was contradicted by the important work of Carlos Diaz Alejandro (1983), Albert Hirshman (1979) and Atilio Boron (1981) on the relations between ideas, authoritarianism, and open economies. Among other things, they raised the issue of systematic torture and forced disappearances not as aberrations but as issues at the heart of IPE. This was classic IPE, building on the political foundations of markets, or the economic foundations of political regimes, at a time when the convertibility of the dollar had been eliminated, the world was awash with liquidity, and markets were desperate to lend money to dictators who, while suppressing dissent, were following Chicago School textbooks about open economies. In fact, this body of political economy highlighted, at the subaltern level of policy, the point made in Cohen's coetaneous Organizing the World's Money (1977): creditors cannot be creditors without debtors.

A second body of thought carried on from analysing the extractive financial role of creditors to flesh out how a mix of tantalising and doomsayer tactics was structured both at the Bretton Woods and the 


\section{A global conversation: rethinking IPE in}

post-hegemonic scenarios

country level - all to facilitate the bitter pill of policy-based lending as the solution to the debt problem. Tussie (1993) attempted to theorise about debt-led trade policy and southern coalition bargaining by focusing on Brazil, India and Argentina. Similarly, the 2000 special issue of Global Governance on civil society and multilateral banks examined the political and economic reshaping spearheaded by the Bretton Woods institutions under democratic rule in Colombia, Brazil, Mexico and Argentina contributed to political economy, here practised and understood as driven by the struggles for (autonomous) development. Finally, from the 1960s onwards, the study of regions was a vibrant field in many guises, first influenced by functionalism but then shaken by the debates over globalisation and, more recently, the rise of emerging economies and post-hegemonic dynamics of regionalisation (Riggirozzi and Tussie 2012). What this suggests is that while IPE unfolded with a continued focus on North Atlantic structures, the structural phenomena in other policy spaces and at other levels of analysis were not given a voice. Despite pretensions to a 'global' scope and relevance, IPE was entrenched in a highly specific geography set around specific issues (Higgott and Watson 2008). Building on Leander (2009) and Phillips (2005), we want to draw attention to and make the case for those 'multiple stories' that define a global conversation in IPE. Phillips (2005) claims that in the IPE project the developing countries, and hence development as such, were relegated to second-class status. Those struggles did not matter because they did not shape the system; scattered trees do not shape a system even though they may fringe it on the edges. By contrast, the 'whole-system' approach of IPE was built on a theoretical and empirical focus on the advanced industrialised powers. In other words, Phillips remarks, 'it is not that trees are ignored per se, but rather that only certain trees are deemed to be of interest, namely those which are seen to determine the nature and form of the wood (ibid: 17). 
In essence, then, the IPE project took up only one region and universalised it, while the rest remained second-class citizens. This resulted in two parallel traditions in IPE that barely touched each other - one that looked at the trees which shaped the 'whole system', and another that analysed chains of dependence, domination, or simply abuse by more powerful actors. In the process, relations among some countries and regions - the 'scattered trees' - that comprise the global political economy were ignored, and development in those regions were seen as simple reflections of the 'global' process.

In the process of contesting this conception, we intend to take up Cohen's call for understanding geography as spaces of rule-making. What IPE scholars need to do is to rethink the field in order to give it a more global reach, and enable it to articulate a vision of how diverse elements of the global political economy come together. It must abandon the self-defensive posture of many regional studies, and move beyond a comparative approach. The great challenge for IPE is to see a decentred world, and broaden its geography beyond the North in order to understand how regions are politically organised and governed, and how they themselves can become actors in providing public goods in their areas while carving out spaces in niche areas of global diplomacy.

\section{Bringing regions back in: from spheres of influence to global governance}

Latin America has a long tradition of diverse regional associations. In some ways, the region is unique because of its shared beginnings in the system of states; its commonality in terms of Iberian as well as indigenous culture (Fawcett 2005); its exposure to the reach of the United States; and its endurance of North American hegemony. In this sense, regionalism as a dense web for the diffusion of policies 


\section{A global conversation: rethinking IPE in}

post-hegemonic scenarios

dates as far back as the struggles for independence and the coetaneous conformation of republics. This is a distinctive birthmark, which also helps to explain the particular trajectory of Latin American regionalism and its mix of contestation, adaptation and pragmatism to a number of political dilemmas. Latin America is set apart from other expressions of regionalism around the world by its time frame, as well as its exposure to a particular set of influences. Frontiers are mostly consolidated, a feature reflected in the lowest levels of armed conflicts among states and the lowest levels of military expenditures in terms of percentages of GNP worldwide. The 1968 Treaty of Tlatelolco prohibited and prevented the use, manufacture, production or acquisition of nuclear weapons at an early stage, turning Latin America into the only continent free from nuclear competition at that time. These commonalities have provided a distinctive analytical and normative frame. Likewise, the economic and political dynamics of the post-Cold War era in the Americas were drivers of regionalism. Consequently, regionalism was often explained as a process of Americanisation (Grugel 1996), based on the hegemonic position of the United States. The United States was perceived as 'disciplining' and policing the region through Cold War alliances such as the Inter-American Treaty of Reciprocal Assistance. Moreover, institutions such as the Organization of American States were meant to organise and provide order while securing regional spheres of influence at the same time (Marini 1977: 20-39; Hirst 2003).

The way in which regionalism unfolded, through spheres of influence, pervaded the economic realm, and defined the political economy of development in ways that embedded the principles of the Washington Consensus in the 1990s. Trade became the mechanism for the transmission and adaptation of neo-liberal principles. New regions were created, such as the North American Free Trade Area (NAFTA) in 1993 and Mercosur in 1991. 
Competition over their potential expansion brought these organisations into opposition from time to time, leading to continued tensions over modes of regional associations and ultimately regional leadership. Mercosur was widely believed to create a window of opportunity for contesting the United States-led mode of regionalism - an opportunity that was largely curtailed by the realities of dependent economies and unstable political systems, but has not lost its vigour. In fact, changing political-economic circumstances, including the changing co-ordinates of trade and power in the region since the early 2000s, meant a jump-start for motivations of autonomous development and regionalism through alternative projects such as the Bolivarian Alternative for the Americas (ALBA), a project forged by the late president Hugo Chavez of Venezuela; and the Union of South American Nations (UNASUR), which is closely associated with Brazil's regional agenda. These projects - which are at odds with North American power, and contest neoliberalism as an hegemonic programme - were not only unprecedented in terms of regional governance but also raised new questions about how coexisting yet competing regionalism in the Americas should be analysed. More recently, the ability of the United States to shape regional orders and institutions has declined. Regions and countries have acquired lives of their own. In Latin America, the ability of the United States to shape regional discourses and institutions suffered a serious blow with the demise of the Free Trade Area of the Americas in 2005. Although we cannot write off North American influence over events south of its border, the regional 'box' has been opened. Regions have been set free, as Hurrell graphically put it (1995), and so have a number of countries that are now seen as regional powers. Regional analysis adds an exciting dimension to the study of international political economy, which focused too closely and for too long on western states and societies. Governments' views of the world and their policies reflect geography as much as any other factor. For those inclined to think in 
A global conversation: rethinking IPE in

post-hegemonic scenarios

terms of stark, binary oppositions between rule-takers and rule-makers, or conceive of international relations as happening at the centre, the change is both welcome and dramatic. In the case of Latin America, the prevalence of a theoretical model in which the United States was seen as enjoying 'perennial predominance' (Smith 2000: 4) over a region seen as a dependent and defenceless object has lost sway. By contrast, the region has become a subject in its own right, and a key driver of world politics. Regional logics now predominate in their own right rather than serving as mere transmission belts of American interests.

Given that contemporary regionalism in Latin America is shaped by the changed geopolitics of the Americas, we propose that this moment be regarded as 'post-hegemonic', and the regional formations that emerged since the early 2000s as 'post-hegemonic regionalism'. The declining influence of the United States, together with the emergence of new policies and particularly the carving out of spaces in niche areas of intervention, have given geography an identity (or 'actorness') as a social construct (Hettne and Söderbaum 2000), and a new place in IPE. What is post-hegemonic regionalism? Three main features can be outlined. Post-hegemonic projects seek to extend the scope of regional co-operation beyond trade, creating political spaces for reworking regional normative frameworks and practices of governance. In Latin America, in line with this, regionalism should be seen as a space where actors re-enact state-society relations on a different level, in ways capable of shaping policy preferences in areas of policy beyond trade and finance. Accordingly, new areas of regional co-operation - including welfare, security and defence, energy, infrastructure, and financial co-operation - have replaced trade as the predominant area of integration.

The re-politicisation of regional co-operation since the early 2000s has resulted in the rebuilding of a developmentalist agenda 
supported by new normative frameworks that emphasise, in contrast with past experiments, rights-based approaches to social development and inclusion. Finally, from an IR perspective, these initiatives are driven by a conscious search for greater autonomy in the international arena and in development policies, particularly vis-à-vis the United States (Riggirozzi and Tussie 2012; also see Sanahuja 2011). Seen in this way, regionalism not only institutionalises trans-border practices, but also reflects transformations of the regional space. What the region means for state and non-state actors can be signified and re-signified as motivations, interests, ideas, narratives, and political and economic policies undergo various changes. Paraphrasing Wendt (1992), the region in the Americas has truly become what actors make of it.

\section{Why regionalism? Implications for research}

Regionalism has reshaped the global political landscape and discourse since the 1990s, when significant regional trade integration took off in lockstep with the literature on globalisation. Scholars embraced the concept of the 'new regionalism' to reflect the complex linkages among regionalism, globalisation and the neoliberal transformation. While the 'old regionalism' of the 1950s to the 1970s manifested regionalised forms of regulated markets and high tariffs, 'new' regional formations were tied to the transnationalisation of trade and production, and the progressive liberalisation of markets in developing countries (Devlin and Estevadordeal 2001; Gomez Mera 2008). New Regionalism (NR) captured the intellectual imagination of scholars concerned with regionalism beyond neo-functionalist understandings of integration based on EU studies. NR was conceived as a systemic approach to the pressures of the international political economy on regions, and their responses to those incentives, rather than the intra-regional 
A global conversation: rethinking IPE in

post-hegemonic scenarios

factors and interdependencies that characterised many of the old approaches, especially neo-functionalism (as expounded by Ernst Haas and others) which had such strong currency in EU studies and which were - for better or worse - emulated around the globe. For $\mathrm{NR}$, the concerns were the construction of regions and regional agents. It focused not only on state-led regional organisations but also on processes of regionalisation, thriving due to (informal) trans-border exchanges between non-state social and business actors. This line of enquiry meant, among other things, that regions were no longer seen as global governance leftovers, or unproblematic or pre-defined spheres of influence.

For many NR scholars, regionalism was part and parcel of global capitalist transformations, manifested regionally as meso-globalisation processes (Phillips 2003). Scholars have thoroughly examined - and speculated about - how structural factors such as the end of communism, the collapse of economies in the developing world following the debt crisis in the early 1980s, and the rise of global finance in the 1980s and 1990s contributed to the 'triumph' of liberal ideas about the centrality of the markets and the inescapable spread of capitalism. In Latin America, this template explained a generalised agreement among mainstream thinkers and policy-makers, business sectors, international aid agencies, financial institutions and governing elites about the failure of market regulation and state-controlled economies, and the promises of open economies (Bouzas 2001). Loosening the restrictions on finance and trade therefore fostered new trade agreements as a hub for new regionalist projects within the fundamental and ongoing neoliberal consensus. From this perspective, earlier versions of new regionalism understood Latin America as part of a North-Americanised system that posited regionalism through locking in linkages with the North American economy. As a governance project, the new regionalism unfolded as a strategy for locking in the market reforms sought by the 
Washington Consensus at a regional level. From this perspective, regionalism was conceived as a building block of global liberalisation through the interplay between state-led macro processes of regulation, and micro and often informal processes of regionalisation led by business and other non-state actors. This persuasive argument proved resistant to many claims about historical roots supporting different pathways to regionalism (Fawcett 2005, Solingen 1998), and the diverse dynamics of co-operation in different areas of policy (Söderbaum and Shaw 2003; Gomez-Mera, 2008; Tussie and Trucco 2010). Regionalism was seen as a manifestation of the global order, envisioned as hegemonic politics triggered by the need to engage efficiently in global market activity. NR went through phases of energetic expansion, of mere trend-following, controlled stalemate, disaggregation and reconfiguration as a result of the ups and downs of development strategies and the changing conditions in global markets. These factors resulted in various forms of regionalism, not only in terms of goals but the nature and scope of policy-making as well. Considerable cross-regional variation became evident in the extent to which regionalism emerged as a response to and a result of globalisation. An extensive body of research confirmed the links between globalisation and regionalism in the Americas, Europe and East Asia. At the same time, a closer scrutiny showed that the emergence and evolution of regional integration agreements in sub-Saharan Africa, the Middle East, and Central and South Asia were less influenced by global economic pressures than by geopolitical and security considerations. In Africa, regional or continental integration agreements were meant to enhance domestic standing and cement state sovereignty, rather than increase the size of markets or respond to global economic challenges (Gomez Mera 2008). Regional and domestic political considerations underpinned the establishment of the Common Market for Eastern and Southern Africa (COMESA) as well as efforts to revitalise the Southern 
A global conversation: rethinking IPE in

post-hegemonic scenarios

African Development Community (SADC) and the East African Community (EAC) in the early and mid-1990s. Similarly, the formation of several regional organisations in the Middle East in the 1980s, including the Gulf Cooperation Council, had more to do with security than with globalisation (Solingen 1998). Regions were no longer seen as simple reflections of the global order, or of spheres of influence, but as wrestling arenas where competing projects competed, revolted, and held out in order to shape distributive outcomes. To take the case of Latin America, and Mexico and Brazil in particular, a micro-institutional revolution swept their political economies in ways that transcended specific administrations (Tussie 2013). The preference of market agents are integrated into state institutions through processes at the national and regional level of analysis. As the pattern of material interests in national political economies became more international, so did state calculations. NR's focus on the linkages between regionalism and globalisation gave way to the explanatory role of power asymmetries, the rational calculations of states, and the design of regional institutions (Gomez Mera 2008). As regions appeared as the result of domestic processes, when projects emerged from 'the nation up', the study of regionalism came much closer to the core traditional concerns of IR. This is a landmark in our understanding of a governance cluster, or what Detlef Nolte (2014) calls a 'regional governance complex'. For some, the presence of regional powers; emerging markets; or 'middle states' with a clear position in the region and the international system, and with certain attributes that allow for leadership are key to explaining the emergence of such clusters (Nel and Nolte 2010). Accordingly, some scholars will argue that middle states will attempt to reproduce their role and interests by developing institutions and forms of co-operation in support of specific needs and models of development, be they oriented towards security, finance or investment. As a result, the region is seen as a construction of authority and order. Although this understanding helps us to think 
of regions as outcomes of power politics and interests, reflecting complex double-edged diplomacy, there are some methodological and analytical difficulties with this approach. First, it attributes a tautological significance to what the region is for, namely the means for stronger states to pursue their interests in a multiscalar way. Second, it overlooks the question of followers. According to Schirm (2010: 199) 'successful leadership depends not only in resources and ambition but also crucially upon the support of followers'. This is an interesting addition to a discussion that portrayed regions as top-down disciplinary mechanisms. The notion of followership adds a relational dimension to the discussion about regional powers. In this view, other than hegemonic politics, region can be constructed on the basis of consensual views and interests that, although advanced and guaranteed by the leader, reflect the position of the followers. Altogether, this implies a transaction between leading and follower states securing some sort of win-win situation in which the leader can use the region as a platform for extending specific interests, and the followers can benefit from 'negotiated' autonomy and otherwise restricted access to resources and markets. This interplay between self-interested actors in the construction of a common order resembles neoliberal theories in IR in terms of which regionalism is equated with regimes (Krasner 1983). From this perspective, leaders and followers join forces based on a functional definition of the common which is advantageous to all parties, even after, despite, or beyond hegemony (Keohane 1984). As Ikenberry (2001: 28) has put it, the order is still organised around asymmetrical relations, but its coercive aspects are 'muted'. As acknowledged by Schirm (2010: 199), while the leaders (emerging powers) provide incentives to their followers, the latter will consider the costs of following against the cost of 'free riding', or following other leaders or established powers such as the United States, or emerging extra-regional ones such as China. 


\section{A global conversation: rethinking IPE in}

post-hegemonic scenarios

In other words, pre-eminence does not guarantee followership, as many argue when examining Brazil. Despite its regional pre-eminence, Brazil has failed to translate its structural and instrumental resources into effective leadership (Malamud 2012). Potential regional followers have not always aligned themselves with Brazil's main foreign policy goals, such as its pursuit of a permanent seat in the United Nations Security Council or the presidency of the Interamerican Development Bank, and its regional influence is challenged and sidestepped. But if the Brazilian leadership is in question, its double-edged diplomacy shows in any case that non-hegemonic leadership still plays a major role in region-building on the bases of a shared search for autonomous development and security, while seeking to keep extra-regional powers at bay. As many scholars have recognised, Brazil's political style and motivations have been guided by economic development rather than regional hegemony. In many ways, its political-economic history has been driven by a tension between the search for power and the search for development (Vigevani and Cepaluni 2007). This tension has supported pragmatic policies towards regional integration and multilateralism. From this perspective, it becomes important to analyse the nature of regional collective action. Do regional leaders recognise collective concerns, or merely use regional spaces as platforms for achieving their national and global interests? One way of addressing this question is precisely by fragmenting the notion of leadership. Leadership and power play important roles in state-led regional programmes, and the establishment of control over and coherence in certain regional arrangements. Yet leadership itself, even as a tool for coherent regional integration, needs no mystification. The success of Brazil lies in the conception of a regional order that includes co-operative relations across a number of issues, such as geographical connections and security. The region is a space for the articulation of shared projects involving actors of different magnitudes, but 
confluent interests. These practices are expressions of a redefinition of regional consensus over social and economic resource-sharing, regulation, planning, and financial co-operation. At the same time, they are laying new foundations for political and social cohesiveness that can be also interpreted as a sense of community-building, or what Söderbaum and Hettne identify in their extensive academic work as regionness.

Regionness denotes two sets of dynamics. The first is a sense of identity and belonging of state and non-state actors to a particular region based on shared values, norms and institutions that govern their interactions and the ways in which they perceive themselves within a common polity (self-recognition). The second denotes cohesive action towards the outside, or recognition by others (Hettne and Söderbaum 2000: 461). In other words, the idea of region as defined by its level of regionness has been portrayed in terms of what defines regionness in terms of organised social, political and economic trans-border relations (material foundations of regionalism), supported by a manifested sense of belonging as well as common goals and values (symbolic foundations). Lastly, regional institutions and regulations enhance the ability of regions to act autonomously in the international arena, which adds to their external recognition as actors. Understood in these terms, regionness was often used to explain the role of the EU as an actor in the international arena, at the risk of falling into a critical comparative analysis that uses the EU as a starting point for analysing other regions and their regionness. Regionalism beyond Europe, and particularly in Latin America, was often seen as part of interest maximisation and dependency management vis-à-vis the global and regional effects of North American policies. From this perspective, Latin America was the 'regional laboratory' for North American policies on trade, investment, services, and government procurement (Serrano 2005:13). In this view, the level of analysis, point of entry, 


\section{A global conversation: rethinking IPE in}

post-hegemonic scenarios

and DNA for understanding identity, common practices and belonging was the global system. Furthermore, a transformative regionalism based on solidaristic practices and identity formation beyond market imperatives was expected to come from networks of non-governmental actors forming coalitions with like-minded groups throughout the hemisphere (Saguier 2007). However, these very causes and demands were taken up by former presidents Hugo Chávez and Luiz Inácio Lula da Silva. Active participants in the World Social Forum, they not only had a heartfelt sense of social commitment to the dispossessed and vulnerable, but also a flair for a deeply personalised diplomacy aimed at making contact with ordinary people and their needs. Slowly but persistently, a novel kind of diplomacy reaching out to the needs of peoples moved on, suggesting an interesting configuration in which agendas advanced by groups resisting neo-liberalism were accepted and to some extent articulated by governments. Both presidents made huge leaps towards strengthening the bonds between social issues and international diplomacy, now 'from the nation up'. What emerges from these trends is an interesting relationship between the use of mobilisation and resistance in which governments try to balance the risk-adverse mind-set of elites with popular disaffection, and adapt to claim-making and mobilising by civil society. New forms of regional politics and organisation under the umbrella of organisations such as UNASUR and ALBA are redefining new geographical and ideological boundaries while fostering new consensuses that are defined in regional instead of global terms, and supported by mainly state-led practices, institutions, and funding mechanisms in new social fields such as education, health, employment, energy, infrastructure and security. Although embryonic, these consensuses are setting new regional boundaries beyond the historical hub of regionalism led by the United States and the market. From this perspective, not only the notion of region is re-signified to reflect new spaces for state action; more 
fundamentally, this is leading to a new rhetoric about what regionalism is and is for. Engaging with this emerging debate, Riggirozzi (2014) proposes that regional governance is about setting normative parameters as much as creating spaces of co-operation for the design and implementation of policies at different levels of authority. From this perspective, Riggirozzi and Grugel (2015) analyse how Latin-American regionalism is shoring up democracy, and managing the regional social deficit.

Other scholars contest the idea of regionalism as neoliberalism, offering prima facie studies of regional groupings in the South affecting the political and social foundations of activism, particularly in the areas of health (Riggirozzi 2015; Fourie 2013), and social economy and trade (Feinsilver 2008). In these areas, the region as geography and regionalism as governance become:

... pivotal for collective action and for contention politics by (i) creating normative frameworks structuring inter-governmental and expert networks model of regional governance; (ii) facilitating the re-allocation of material and knowledge resources in support of public policy and policy implementation; and (iii) enabling new dynamics of representation and diplomacy (Riggirozzi 2014: 451).

Ultimately, post-hegemonic regionalism in the South is redefining social activism and political practices in ways that broaden the arena of action beyond communities and nation-states, and relocating regionalism as an extension of domestic politics rather than a by-product of global politics. From such a perspective, regions must be seen as social and political constructions, and hence areas which themselves produce a dynamic that affects the corridors of norm creation and diffusion. 


\section{A global conversation: rethinking IPE in post-hegemonic scenarios}

The new emphasis on social development, democracy, and inclusion not only brings regionalism closer to the ordinary people through new regional interventions, but also calls attention to how we study the role of regionalism in IPE. The 'woods, not the trees' approach of mainstream IPE is faced with at least two challenges. The first has to do with the relational dialectic in the global political economy; how to explain projects such as UNASUR and ALBA that embrace new discursive and ideational patterns as well as practices based on alternative interpretations of what regionalism is about. These developments, together with the re-invention of some principles of collectivism and social welfare, may even result in a deconstruction of the region, and a re-construction of regions as spaces or arenas for debate and action. The second has to do with the geopolitics of academia. The important point to advance in a genuinely global conversation is that the outside-in dynamic, where the local can swiftly be seen as a reflection of the global, but the inside-out dynamic is overlooked. When we see the domestic political economy projected outwards, regional actors gain autonomy and actorness, or 'a degree of insulation from outside pressures' (Cohen 2008b: 455).

Regionalism in the South is a call to transcend not only transatlantic divides but also inside-outside conceptualisations of regionalism that overlook the complexity of broader political economic processes linked to new commitments of inclusion and citizenship. Even if embryonic, the logic of regionalism led by the state but with an enormous impact on new areas of social development reveal a nuance that is not fully grasped by arbitrary distinctions between what states do and what non-state actors do. This does not mean that capitalism, liberalism, and trade-related forms of integration have ceased to exist, or ceased to capture the regional agenda. Business interests are unlikely to release that space of privilege. However, it does mean that their centrality is being displaced, as the co-ordinates that define policies and politics in the global political economy and the corridors of power are reworked by many actors in different geographies. 


\section{Conclusion}

IPE is one of the most innovative and diverse fields of study in contemporary social science, in no small measure owing to Cohen's contributions. One frequently hears assertions that all good political economy is 'international' in any case, and undoubtedly Cohen has had a considerable hand in fostering this recognition. Yet all good political economy must also be rooted in national agents and structures. Cohen's call has stressed the need to articulate 'otherness', and open up the Atlanticism that curtails the reach of IPE. This contention is important not only for its theoretical implications but also for the ways in which it can open up research agendas in post-hegemonic scenarios.

Pulling our own threads together, we need to dispense with the dichotomy between the global and the national, or systemic and locally contingent determinants. Our discipline needs to make progress by stealth and illuminate the worlds beyond, taking up a research programme that is not obsessed with 'scientific' aspirations which hardly apply - the testing of hypotheses, modelling for the sake of modelling, or simplifying levels of analysis for the sake of order. The newcomers in the non-north Atlantic need to wake up too, and continue to add issue after issue, problem after problem, in order to 'lengthen the shadow of the future' of the IPE project, and unearth areas where the role of regional or national agency is neglected. Recent research shows that developing countries in Latin America, Asia, and Africa played a significant but hitherto unacknowledged or forgotten role in creating post-war norms and institutions related to human rights, sovereignty, and international development (Global Governance 2014: 359-417). In line with this, we call for regions and regionalism beyond institutionalist and trade-based approaches to be taken more seriously in IPE research.

This call applies especially to Latin American scholars, who still tend to think in terms of dichotomies defining levels of analysis. While 


\section{A global conversation: rethinking IPE in post-hegemonic scenarios}

IPE is widely framed in terms of first and second-order issues, Latin American scholars still tend to work in terms of interlacing (exogenous) structures or policy processes with (endogenous) country-level understandings of development. Unifying these traditions would create a flexible analytical toolkit for explaining change which would allow an appreciation of both the 'wood' and the 'trees'. In essence, the central aim is to understand the relationship between development processes and their structural contexts. This is where the need for new thinking is most pressing. We need work by scholars who believe that change is not only possible but is happening already, and that, despite the many stumbling blocks and disappointments along the way, we should remember - without anger, but still remember - that large patches of unreformed reality remain.

\section{Note}

1. To name just a few from a list of vibrant and very productive scholars, all in close contact with the traumas of American expansionism in the hemisphere and with theories of imperialism: María de Concepcion Tavares, Jose Luis Fiori, Mario Rapaport, Atilio Boron, Enrique Arceo, Alberto Acosta.

\section{References}

Boron, Atilio. 1981. 'Latin America: between Hobbes and Friedman'. New Left Review 1 (130): 45-66.

Bouzas, Roberto. 2001. 'MERCOSUR Diez Años Después: Proceso de Aprendizaje o Déjà vu?'. Desarrollo Económico 41(1): 179-200. 


\section{Diana Tussie and Pia Riggirozzi}

Cohen, Benjamin J. 1977. Organizing the world's money: the political economy of international monetary relations. New York: Basic Books.

1998. The geography of money. Ithaca: Cornell University Press.

2007. 'The Transatlantic divide: why are American and British IPE so different?'. Review of International Political Economy 14 (2): 197-219.

2008a. 'On currency wars and reviving the "political" in international political Economy'. In P Schouten, Theory Talks \#17\#. At http://www. theorytalks.org/2008/09/theory-talk-17.html (accessed on 22 March 2015).

2008b. 'The international monetary system: diffusion and ambiguity'. International Affairs 84 (3): 455-470.

2014. Advanced introduction to international political economy. Cheltenham: Elgar.

Devlin, Robert and Antoni Estevadeordeal. 2001. 'What's new in the new regionalism in the Americas?' Inter-American Development Bank. At http://www11.iadb.org/WMSFiles/products/research/files/pubS-106.pdf (accessed on 10 March 2015).

Díaz Alejandro, Carlos F. 1983. 'Open economy, closed polity?'. In Diana Tussie (ed), Latin America in the world economy: new perspectives. Aldershot: Gower, 267-291.

Fawcett, Louise. 2005. 'The origins and development of the regional idea in the Americas'. In Louise Fawcett and Monica Serrano (eds), Regionalism and governance in the Americas: continental drift. London: Palgrave-Macmillan.

Feinsilver, Julie M. 2008. 'Médicos por petróleo: La diplomacia médica cubana recibe una pequeña ayuda de sus amigos'. Nueva Sociedad, 216: 107-122. At: $<$ http://www.nuso.org/upload/articulos/3537_1.pdf> (accessed in March 2015).

Fourie Pieter. 2013. 'Turning dread into capital: South Africa's AIDS diplomacy'. Globalization and Health 9 (8). At: <http://www. globalizationandhealth.com/content/9/1/8> (accessed on 15 June 2015).

Global Governance. 2000. 'Special issue: Civil society and multilateral development banks'. 6 (4): 399-518. 


\section{A global conversation: rethinking IPE in post-hegemonic scenarios}

2014. 'Special section: Principles from the periphery: the neglected southern sources of global norms'. 20 (3): 359-417.

Gomez-Mera, Laura. 2008. "How "new" is the "New Regionalism" in the Americas? The case of MERCOSUR'. Journal of International Relations and Development 11: 279-308.

Grugel, Jean. 1996. 'Latin America and the remaking of the Americas'. In Andrew Gamble and Anthony Payne (eds), Regionalism and world order. London: Macmillan, pp. 131-167.

2004. 'New Regionalism and modes of governance: comparing US and EU strategies in Latin America'. European Journal of International Relations 10 (4): 603-626.

Grugel, Jean and Pia Riggirozzi (eds). 2012. Governance afterneoliberalism in Latin America. Basingstoke: Palgrave-Macmillan.

Guzzini, Stefano. 2013. Power, realism and constructivism. Oxford and New York: Routledge.

Hettne, Björn and Fredrik Söderbaum. 2000. 'Theorising the rise of regionness'. New Political Economy 5 (3): 457-473.

Higgot, Richard and Matthew Watson. 2008. 'All at sea in a barbed wire canoe: Professor Cohen's transatlantic voyage in IPE'. Review of International Political Economy 15 (1): 1-17.

Hirschman, Albert O. 1979. 'The turn to authoritarianism in Latin America and the search for its economic determinants'. In David Collier (ed), The New Authoritarianism in Latin America. Princeton: Princeton University Press, pp. 61-80.

Hirst, Monica. 2003. 'Los claroscuros de la seguridad regional en las Américas'. Nueva Sociedad 185: 83-101.

Hurrell, Andrew. 1995. 'O ressurgimento do regionalismo na política mundial'. Contexto Internacional 1 (2): 23-59.

Keohane, Robert. 2001. 'Between vision and reality: variables in Latin American foreign policy'. In Joseph Tulchin and Ralph Espach (eds), Latin America in the new international system. Boulder, Colorado: Lynne Rienner. 


\section{Diana Tussie and Pia Riggirozzi}

Leander, Anna. 2009. 'Why we need multiple stories about the global political economy'. Review of International Political Economy 16 (2): 321-328.

Marini, Ruy Mauro. 1977. 'La acumulación capitalista mundial y el sub-imperialismo'. Cuadernos Políticos 12, abril-junio.

Murphy, Craig N. 2011. 'Do the left-out matter?' In Nicola Phillips and Catherine Weaver (eds), International political economy: debating the past, present and future. Oxford and New York: Routledge, pp. 160-168.

Nel Philip and Detlef Nolte. 2010. 'Introduction: special section on regional powers in a changing global order'. Review of International Studies 36 (4): 877-879.

Nolte, Detlef. 2014. 'Latin America's new regional architecture: a cooperative or segmented regional governance complex?' RSCAS Working Paper no 89. At: <http://www.giga-hamburg.de/de/publication/latin-americas-newregional-architecture-a-cooperative-or-segmented-regional-governance $>$ (accessed on 10 March 2015).

Phillips, Nicola. 2003. 'Hemispheric integration and subregionalism in the Americas'. International Affairs 79 (2): 327-349.

. 2005. Globalizing international political economy. London: Palgrave MacMillan.

Quijada, Monica. 1998. 'Sobre el origen y difusión del nombre "América Latina" (o una variación heterodoxa en torno al tema de la construcción social de la verdad)'. Revista de Indias 58 (214).

Quiliconi, Cintia. 2013. 'Modelos competitivos de integración en el hemisferio occidental: ¿liderazgo competitivo o negación mutua?'. Revista CIDOB d'Afers Internacionals 102 (103): 147-168.

Riggirozzi, Pia. 2014. 'Regionalism through social policy: collective action and health diplomacy in South America'. Economy and Society 43 (3): 432-454.

Riggirozzi, Pia and Diana Tussie (eds). 2012. The rise of post-hegemonic regionalism: the case of Latin America. United Nations University series on regionalism. New York: Springer.

Riggirozzi, Pía and Jean Grugel. 2015. 'Regional governance and legitimacy in South America: the meaning of UNASUR'. International Affairs, 91(4): 781-797. 


\section{A global conversation: rethinking IPE in post-hegemonic scenarios}

Saguier, Marcelo I. 2007. 'The hemispheric social alliance and the Free Trade Area of the Americas process: the challenges and opportunities of transnational coalitions against neo-liberalism'. Globalisations 4 (2): 251-265.

Sanahuja, José Antonio. 2011, 'Multilateralismo y regionalismo en clave suramericana: el caso de UNASUR'. Pensamiento Propio: los desafíos del multilateralismo en América Latina 33 (16): 115-156.

Serbin, Andrés. 2009. 'América del Sur en un mundo multipolar: ¿es la UNASUR la alternativa?'. Nueva Sociedad 219: 145-156.

Serrano, Monica. 2005. 'Regionalism and governance: a critique'. In Louise Fawcett and Monica Serrano (eds), Regionalism and governance in the Americas: continental drift. Basingstoke: Palgrave Macmillan. 1-24.

Smith, Peter H. 2000. Talons of the eagle: dynamics of US-Latin American relations. New York and Oxford: Oxford University Press.

Solingen, Etel. 1998. Regional orders at century's dawn: global and domestic influences on grand strategy. Princeton: Princeton University Press.

Tussie, Diana. 1993. The developing countries in world trade: policies and bargaining strategies. Boulder, Colorado: Lynne Rienner.

2003. 'Regionalism: providing substance to multilateralism?' In F Söderbaum and T Shaw (eds), Theories of New Regionalism. London: Palgrave MacMillan, pp. 99-116.

2013. 'Os imperativos do Brasil no desafiador espaço regional da América do Sul: uma visão de política econômica internacional'. Lua Nova 90. At http://www.scielo.br/scielo.php?pid=S0102-64452013000300009\& script=sci_arttext (accessed in March 2015).

Tussie, Diana and Pablo Trucco (comp). 2010. Nación y región. Buenos Aires: Teseo.

Vigevani, Tullo and Gabriel Cepaluni. 2007. 'A política externa de Lula da Silva: a estratégia da autonomia pela diversificação'. Contexto Internacional 29 (2): 273-335. At: <http://www.scielo.br/scielo.php?script=sci_ arttext\&pid=S0102-85292007000200001 > (accessed in March 2015).

Wendt, Alexander. 1992. 'Anarchy is what states make of it: the social construction of power politics'. International Organization 46: 391-425. 


\section{Abstract}

\section{A global conversation: rethinking IPE in post-hegemonic scenarios}

Benjamin Cohen has provoked us into a global conversation aimed at unwrapping the practice and study of IPE. In this article, we build upon his powerful notion of geography as politics, and engage afresh with the role of regions as correctives to debates on developmental strategies and trajectories in the global political economy. We share Cohen's view that 'how we conceive of space has a real impact on how we think about rule-making' (1998: 10), and argue that regions take shape iteratively via social and political processes that differ both temporally and geographically. As such, the key question for IPE is not whether regionalism exists, but rather what kind of regional governance is taking shape, and how it fits into IPE's globalist soul-searching. With this in mind, we analyse various conceptions of regions over time, from spheres of influence to governance actors, marking important differences (in symbolic, practical and institutional terms) in relation to experiments of the past. In doing so, we seek to underline at least the value of giving greater attention to the place of regions and regionalism in IPE's global conversation.

Keywords: Benjamin Cohen - Post-Hegemonic Regionalism - Regional Governance - Global Orders - Regions as Actors 